\title{
KESESUAIAN CONTENT REPRESENTATION DENGAN SIMULASI MENGAJAR CALON GURU BIOLOGI DAN DIKAITKAN DENGAN PENGETAHUAN KONTEN DAN PEDAGOGY PADA KONSEP EKOLOGI
}

\author{
Mega Elvianasti \\ Universitas Muhammadiyah Prof. Dr. Hamka \\ email: megaelvianasti@uhamka.ac.id
}

\begin{abstract}
Teaching simulation is a way for a prospective teacher to represent his/ her content knowledge (CK) and pedagogical knowledge (PK) into a teaching situation that is made similar to the actual situation. This study aims to analyze CoRe's suitability with teaching simulations and is associated with content knowledge and pedagogy that is owned by prospective biology teachers. The data used to analyze content knowledge is in the form of CoRe documents and mastery tests of Ecological concepts, while the data used to analyze pedagogical knowledge is in the form of pedagogical mastery tests, as well as teaching simulation observation guidelines to observe the suitability of teaching simulations with CoRe documents that have been prepared. The results and conclusions in this study were: Research Subjects 1 had high content mastery, and high pedagogical mastery. There is a match between the teaching simulation and the CoRe document. Research subjects 2, had low content mastery, and high pedagogical mastery. Some points are not in accordance with CoRe preparation documents with teaching simulations. Research subjects 3, had low content mastery, and low pedagogical mastery. The CoRe document discrepancies with teaching simulations. Research subjects 4, have high content mastery, and moderate pedagogy mastery. There is a match between the teaching simulation and the CoRe document. Research subjects 5, had low content mastery, and low pedagogical mastery. The CoRe document discrepancies with teaching simulations. As a conclusion, prospective teachers who have high content and high pedagogy have CoRe compatibility with teaching simulations, and vice versa. However, there are prospective teachers who have high pedagogy and low content; there are incompatibilities with CoRe with teaching simulations.
\end{abstract}

\section{Keywords: Teaching Simulation, Content Representation, Knowledge Content, Pedagogical Knowledge}

\begin{abstract}
Abstrak: Simulasi mengajar merupakan suatu cara bagi seorang calon guru dalam merepresentasikan pengetahuan konten $(\mathrm{CK})$ dan pengetahuan pedagogi (PK) yang dimilikinya ke dalam situasi mengajar yang dibuat mirip dengan keadaan yang sebenarnya. Penelitian ini bertujuan untuk menganalisis kesesuaian CoRe dengan simulasi mengajar dan dikaitkan dengan pengetahuan konten dan pedagogy yang dimiliki oleh calon guru biologi. Data yang digunakan untuk menganalisis pengetahuan konten adalah berupa dokumen CoRe dan tes penguasaan konsep Ekologi, sedangkan data yang digunakan untuk menganalisis pengetahuan pedagogi adalah berupa tes penguasaan pedagogi, serta pedoman observasi simulasi mengajar untuk mengamati kesesuaian simulasi mengajar dengan dokumen CoRe yang telah disusun. Hasil dan kesimpulan dalam penelitian ini adalah : Subjek Penelitian 1 memiliki penguasaan konten tinggi, dan penguasaan pedagogi tinggi. Terdapat kesesuaian antara simulasi mengajar dengan dokumen CoRe. Subjek penelitian 2, memiliki penguasaan konten rendah, dan penguasaan pedagogi tinggi. Beberapa point ada yang tidak sesuai dengan dokumen penyusunan CoRe dengan simulasi mengajar. Subjek penelitian 3, memiliki penguasaan konten rendah, dan penguasaan pedagogi rendah. Ketidaksesuaian dokumen CoRe dengan simulasi mengajar. Subjek penelitian 4, memiliki penguasaan konten tinggi, dan penguasaan pedagogi sedang.
\end{abstract}


Terdapat kesesuaian antara simulasi mengajar dengan dokumen CoRe. Subjek penelitian 5, memiliki penguasaan konten rendah, dan penguasaan pedagogi rendah. Ketidaksesuaian dokumen CoRe dengan simulasi mengajar. Sehingga dapat disimpulkan bahwa calon guru yang memiliki konten tinggi dan pedagogi tinggi terdapat kesesuaian CoRe dengan simulasi mengajar, dan sebaliknya. Akan tetapi,ada calon guru yang memiliki pedagogi tinggi dan konten rendah terdapat ketidaksesuian CoRe dengan simulasi mengajar.

Kata kunci: Simulasi Mengajar, Content Representation, Pengetahuan Konten, Pengetahuan Pedagogi

\section{PENDAHULUAN}

Simulasi mengajar merupakan suatu cara bagi seorang calon guru dalam merepresentasikan pengetahuan konten (CK) dan pengetahuan pedagogi (PK) yang dimiliknya ke dalam situasi mengajar yang dibuat mirip dengan keadaan sebenarnya. Simulasi mengajar bertujuan untuk menerapkan pembelajaran tiruan dengan suatu metode yang sudah dipilih kepada teman, sehingga dapat diaplikasikan dalam situasi yang nyata di dalam kelas. Simulasi mengajar berbeda dengan praktek mengajar, karena simulasi mengajar hanya dilakukan dengan teman sebaya sedangkan praktek mengajar dilakukan antara calon guru dan siswa. Jadi, praktek mengajar dilakukan secara real di lingkungan sekolah.

"Basically, content mastery is the ability of a person to re-express a particular object based on the characteristics possessed by the object. Concepts, principles and structures of knowledge and problem solving are important learning outcomes in the cognitive domain. Content knowledge (Knowledge Knowledge) is a very important knowledge possessed by a teacher, no doubt that someone who wants to become a professional teacher must have this knowledge well. One aspect of the teacher who has the good qualities of the No Child Left Bebind Act in Lenhart (2006) is to have the breadth and depth of content". Guru yang memiliki pemahaman yang mendalam mengenai suatu konten akan membantu siswa mencapai pemahaman tentang "bagaimana dan mengapa" topik dan konsep-konsep tertentu saling berhubungan (Hagevik et al, 2009). Data penguasaan konten ekologi calon guru diperoleh dari tes penguasaan Ekologi dalam (Elvianasti, 2018) dan dokumen CoRe (Content Representation). Tidak hanya kemampuan CK, guru juga dituntut untuk menguasai pengetahuan pedagogi (PK), Shulman menyatakan bahwa PK adalah teori atau keyakinan tentang mengajar dan proses pembelajaran. Proses ini berkaitan dengan cara dan proses mengajar yang meliputi pengetahuan tentang manajemen kelas, tugas, perencanaan pembelajaran, dan pembelajaran siswa (Hudson, 2007). Data penguasaan pedagogi diperoleh dari tes penguasaan pedagogi dalam (Elvianasti, 2016). 
Loughran, Mulhall and Berry (2006) mengembangkan suatu metode yaitu, Content Representation (CoRe) dan Professional experience Repertoires (PaP-eR). CoRe berisi uraian konsepkonsep atau materi yang penting dalam mengajarkan suatu topik tertentu. CoRe digunakan untuk mengakses pemahaman guru sains mengenai konten atau materinya. Sedangkan PaPeRs merupakan cara bagaimana konten tersebut disampaikan dan untuk menunjukkan implementasi dari aspek-aspek CoRe. Melalui PaP-eR kita dapat melihat situasi di dalam proses belajar mengajar yang akan menentukan pedagogi. Kemunculan CoRe ini akan disesuaikan dengan simulasi mengajar dengan menggunakan pedoman observasi.

Penelitian ini bertujuan untuk menganalisis kesesuaian CoRe dengan kegiatan simulasi mengajar calon guru yang dikaitkan dengan pengetahuan konten ekologi dan pedagogi yang dimiliki masing-masing calon guru.

\section{METODE}

Jenis penelitian ini adalah penelitian deskriptif, sejalan dengan apa yang dijelaskan (McMillan dan Schumacher, 2001) metode ini tidak memberikan perlakuan, manipulasi, atau pengubahan pada variabel-variabel bebas, tetapi menggambarkan sesuatu kondisi apa adanya. Populasi pada penelitian ini adalah mahasiswa calon guru biologi semester 6 dan sampelnya adalah mahasiswa calon guru biologi sebanyak 5 orang di Universitas Pendidikan Indonesia (UPI).

Prosedur Penelitian meliputi: 1)Persiapan. Mahasiswa calon guru biologi diberikan tes penguasaan konten dan penguasaan pedagogi kemudian diminta untuk menyusun dokumen CoRe. 2) Pelaksanaan. Mahasiswa calon guru biologi melakukan simulasi mengajar sesuai dengan subkonsep ekologi. 3) Pengamatan. Selama calon guru melakukan simulasi mengajar, observer melihat kesesuaian antara dokumen CoRe yang telah disusun dengan menggunakan pedoman observasi. Data yang digunakan untuk menganalisis pengetahuan konten adalah berupa dokumen CoRe (Content Representation) dan tes penguasaan konsep Ekologi, sedangkan data yang digunakan untuk menganalisis pengetahuan pedagogi adalah tes penguasaan pedagogi, serta pedoman observasi simulasi mengajar untuk mengamati kesesuaian simulasi mengajar dengan dokumen CoRe yang telah disusun 
HASIL

Tabel 1. Pedoman Observasi Simulasi Mengajar Subjek Penelitian 1

\begin{tabular}{|c|c|c|c|}
\hline No & Pernyataan & Ya & Tidak \\
\hline \multicolumn{4}{|c|}{ Kesesuaian kegiatan dengan CoRe } \\
\hline 1 & Pengajaran sesuai dengan ide atau konsep yang dituangkan dalam CoRe & $\mathrm{V}$ & \\
\hline 2 & Menekankan pentingnya mempelajari konsep & & $\mathrm{V}$ \\
\hline 3 & $\begin{array}{l}\text { Menyampaikan ide atau konsep yang belum diketahui oleh peserta didik yang } \\
\text { tertuang dalam CoRe }\end{array}$ & & $\mathrm{V}$ \\
\hline 4 & Dapat menangani kesulitan yang terjadi dalam kegiatan pembelajaran & $\mathrm{V}$ & \\
\hline 5 & Meluruskan kemungkinan kesalahan konsep yang terjadi dalam pembelajaran & $\mathrm{V}$ & \\
\hline 6 & $\begin{array}{l}\text { Mempertimbangkan faktor-faktor tertentu yang tertuang dalam CoRe dalam } \\
\text { pembelajaran }\end{array}$ & & $\mathrm{V}$ \\
\hline 7 & Kegiatan pembelajaran sesuai dengan alur yang dirancang dalam CoRe & & $\mathrm{V}$ \\
\hline 8 & Mengevaluasi pemahaman peserta didik sesuai teknik dalam CoRe & $\mathrm{V}$ & \\
\hline 9 & Memanfaatkan teknologi dalam pembelajaran & $\mathrm{V}$ & \\
\hline 10 & $\begin{array}{l}\text { Menanggulangi keterbatasan di sekolah sesuai dengan cara yang diungkapkan } \\
\text { dalam CoRe }\end{array}$ & $\mathrm{V}$ & \\
\hline \multicolumn{4}{|c|}{ Pengetahuan Konten Saat Simulasi Mengajar } \\
\hline 11 & Menyederhanakan materi sesuai dengan tingkat abstraksi peserta didik & V & \\
\hline 12 & Memberikan contoh yang relevan dengan tingkat abstraksi peserta didik & $\mathrm{V}$ & \\
\hline 13 & Memberikan contoh yang dekat dengan kehidupan peserta didik & V & \\
\hline 14 & $\begin{array}{l}\text { Mengorganisasikan konsep dari yang paling sederhana menuju yang lebih } \\
\text { kompleks }\end{array}$ & $\mathrm{V}$ & \\
\hline 15 & Menghubungkan materi pelajaran dengan pengalaman peserta didik & $\mathrm{V}$ & \\
\hline \multicolumn{4}{|c|}{ Pengetahuan Pedagodi saat Simulasi Mengajar } \\
\hline 16 & Metode/pendekatan yang digunakan sesuai dengan karakteristik materi & & $\mathrm{V}$ \\
\hline 17 & $\begin{array}{l}\text { Mendorong peserta didik untuk berinteraksi dengan bahan ajar melaui } \\
\text { pertanyaan }\end{array}$ & & $\mathrm{V}$ \\
\hline 18 & Mengembangkan keterampilan proses peserta didik & & $\mathrm{V}$ \\
\hline 19 & Mengembangkan kemampuan bernalar peserta didik & & $\mathrm{V}$ \\
\hline 20 & $\begin{array}{l}\text { Memberi kesempatan bagi peserta didik untuk berinteraksi dengan peserta } \\
\text { didik lain }\end{array}$ & $\mathrm{V}$ & \\
\hline 21 & $\begin{array}{l}\text { Memfasilitasi peserta didik untuk menyusun kesimpulan sendiri atau } \\
\text { mengidentifikasi konsep-konsep penting }\end{array}$ & V & \\
\hline
\end{tabular}

Tabel 2. Pedoman Observasi Simulasi Mengajar Subjek Penelitian 2

\begin{tabular}{|c|c|c|c|}
\hline No & Pernyataan & Ya & Tidak \\
\hline \multicolumn{4}{|c|}{ Kesesuaian kegiatan dengan CoRe } \\
\hline 1 & Pengajaran sesuai dengan ide atau konsep yang dituangkan dalam CoRe & $\mathrm{V}$ & \\
\hline 2 & Menekankan pentingnya mempelajari konsep & $\mathrm{V}$ & \\
\hline 3 & $\begin{array}{l}\text { Menyampaikan ide atau konsep yang belum diketahui oleh peserta didik yang } \\
\text { tertuang dalam CoRe }\end{array}$ & & $\mathrm{V}$ \\
\hline 4 & Dapat menangani kesulitan yang terjadi dalam kegiatan pembelajaran & & $\mathrm{V}$ \\
\hline 5 & Meluruskan kemungkinan kesalahan konsep yang terjadi dalam pembelajaran & & $\mathrm{V}$ \\
\hline 6 & $\begin{array}{l}\text { Mempertimbangkan faktor-faktor tertentu yang tertuang dalam CoRe dalam } \\
\text { pembelajaran }\end{array}$ & & $\mathrm{V}$ \\
\hline 7 & Kegiatan pembelajaran sesuai dengan alur yang dirancang dalam CoRe & & $\mathrm{V}$ \\
\hline 8 & Mengevaluasi pemahaman peserta didik sesuai teknik dalam CoRe & $\mathrm{V}$ & \\
\hline 9 & Memanfaatkan teknologi dalam pembelajaran & $\mathrm{V}$ & \\
\hline 10 & $\begin{array}{l}\text { Menanggulangi keterbatasan di sekolah sesuai dengan cara yang diungkapkan } \\
\text { dalam CoRe }\end{array}$ & $\mathrm{V}$ & \\
\hline
\end{tabular}




\begin{tabular}{|c|c|c|c|}
\hline \multicolumn{4}{|c|}{ Pengetahuan Konten saat Simulasi Mengajar } \\
\hline 11 & Menyederhanakan materi sesuai dengan tingkat abstraksi peserta didik & $\mathrm{V}$ & \\
\hline 12 & Memberikan contoh yang relevan dengan tingkat abstraksi peserta didik & $\mathrm{V}$ & \\
\hline 13 & Memberikan contoh yang dekat dengan kehidupan peserta didik & $\mathrm{V}$ & \\
\hline 14 & $\begin{array}{l}\text { Mengorganisasikan konsep dari yang paling sederhana menuju yang lebih } \\
\text { kompleks }\end{array}$ & $\mathrm{V}$ & \\
\hline 15 & Menghubungkan materi pelajaran dengan pengalaman peserta didik & V & \\
\hline \multicolumn{4}{|c|}{ Pengetahuan Pedagogi saat Simulasi Mengajar } \\
\hline 16 & Metode/pendekatan yang digunakan sesuai dengan karakteristik materi & & V \\
\hline 17 & $\begin{array}{l}\text { Mendorong peserta didik untuk berinteraksi dengan bahan ajar melaui } \\
\text { pertanyaan }\end{array}$ & & $\mathrm{V}$ \\
\hline 18 & Mengembangkan keterampilan proses peserta didik & & $\mathrm{V}$ \\
\hline 19 & Mengembangkan kemampuan bernalar peserta didik & & $\mathrm{V}$ \\
\hline 20 & $\begin{array}{l}\text { Memberi kesempatan bagi peserta didik untuk berinteraksi dengan peserta didik } \\
\text { lain }\end{array}$ & $\mathrm{V}$ & \\
\hline 21 & $\begin{array}{l}\text { Memfasilitasi peserta didik untuk menyusun kesimpulan sendiri atau } \\
\text { mengidentifikasi konsep-konsep penting }\end{array}$ & $\mathrm{V}$ & \\
\hline
\end{tabular}

Tabel 3. Pedoman Observasi Simulasi Mengajar Subjek Penelitian 3

\begin{tabular}{|c|c|c|c|}
\hline No & Pernyataan & Ya & Tidak \\
\hline \multicolumn{4}{|c|}{ Kesesuaian kegiatan dengan CoRe } \\
\hline 1 & Pengajaran sesuai dengan ide atau konsep yang dituangkan dalam CoRe & & V \\
\hline 2 & Menekankan pentingnya mempelajari konsep & V & \\
\hline 3 & $\begin{array}{l}\text { Menyampaikan ide atau konsep yang belum diketahui oleh peserta didik } \\
\text { yang tertuang dalam CoRe }\end{array}$ & & $\mathrm{V}$ \\
\hline 4 & Dapat menangani kesulitan yang teriadi dalam kegiatan pembelajaran & & V \\
\hline 5 & Meluruskan kemungkinan kesalahan konsep yang terjadi dalam pembelajaran & & $\mathrm{V}$ \\
\hline 6 & $\begin{array}{l}\text { Mempertimbangkan faktor-faktor tertentu yang tertuang dalam CoRe dalam } \\
\text { pembelajaran }\end{array}$ & & V \\
\hline 7 & Kegiatan pembelajaran sesuai dengan alur yang dirancang dalam CoRe & V & \\
\hline 8 & Mengevaluasi pemahaman peserta didik sesuai teknik dalam CoRe & V & \\
\hline 9 & Memanfaatkan teknologi dalam pembelajaran & $\mathrm{V}$ & \\
\hline 10 & $\begin{array}{l}\text { Menanggulangi keterbatasan di sekolah sesuai dengan cara yang diungkapkan } \\
\text { dalam CoRe }\end{array}$ & & $\mathrm{V}$ \\
\hline \multicolumn{4}{|c|}{ Pengetahuan Konten saat Simulasi Mengajar } \\
\hline 11 & Menyederhanakan materi sesuai dengan tingkat abstraksi peserta didik & V & \\
\hline 12 & Memberikan contoh yang relevan dengan tingkat abstraksi peserta didik & V & \\
\hline 13 & Memberikan contoh yang dekat dengan kehidupan peserta didik & $\mathrm{V}$ & \\
\hline 14 & $\begin{array}{l}\text { Mengorganisasikan konsep dari yang paling sederhana menuju yang lebih } \\
\text { kompleks }\end{array}$ & $\mathrm{V}$ & \\
\hline 15 & Menghubungkan materi pelajaran dengan pengalaman peserta didik & & $\mathrm{V}$ \\
\hline \multicolumn{4}{|c|}{ Pengetahuan Pedagogi saat Simulasi Mengajar } \\
\hline 16 & Metode/pendekatan yang digunakan sesuai dengan karakteristik materi & $\mathrm{V}$ & \\
\hline 17 & $\begin{array}{l}\text { Mendorong peserta didik untuk berinteraksi dengan bahan ajar melaui } \\
\text { pertanyaan }\end{array}$ & & $\mathrm{V}$ \\
\hline 18 & Mengembangkan keterampilan proses peserta didik & & V \\
\hline 19 & Mengembangkan kemampuan bernalar peserta didik & & $\mathrm{V}$ \\
\hline 20 & $\begin{array}{l}\text { Memberi kesempatan bagi peserta didik untuk berinteraksi dengan peserta } \\
\text { didik lain }\end{array}$ & $\mathrm{V}$ & \\
\hline 21 & $\begin{array}{l}\text { Memfasilitasi peserta didik untuk menyusun kesimpulan sendiri atau } \\
\text { mengidentifikasi konsep-konsep penting }\end{array}$ & $\mathrm{V}$ & \\
\hline
\end{tabular}


Tabel 4. Pedoman Observasi Simulasi Mengajar Subjek Penelitian 4

\begin{tabular}{|c|c|c|c|}
\hline No & Pernyataan & Ya & Tidak \\
\hline \multicolumn{4}{|c|}{ Kesesuaian kegiatan dengan CoRe } \\
\hline 1 & Pengajaran sesuai dengan ide atau konsep yang dituangkan dalam CoRe & $\mathrm{V}$ & \\
\hline 2 & Menekankan pentingnya mempelajari konsep & $\mathrm{V}$ & \\
\hline 3 & $\begin{array}{l}\text { Menyampaikan ide atau konsep yang belum diketahui oleh peserta didik yang } \\
\text { tertuang dalam CoRe }\end{array}$ & $\mathrm{V}$ & \\
\hline 4 & Dapat menangani kesulitan yang terjadi dalam kegiatan pembelajaran & $\mathrm{V}$ & \\
\hline 5 & Meluruskan kemungkinan kesalahan konsep yang terjadi dalam pembelajaran & $\mathrm{V}$ & \\
\hline 6 & $\begin{array}{l}\text { Mempertimbangkan faktor-faktor tertentu yang tertuang dalam CoRe dalam } \\
\text { pembelajaran }\end{array}$ & & $\mathrm{V}$ \\
\hline 7 & Kegiatan pembelajaran sesuai dengan alur yang dirancang dalam CoRe & $\mathrm{V}$ & \\
\hline 8 & Mengevaluasi pemahaman peserta didik sesuai teknik dalam CoRe & $\mathrm{V}$ & \\
\hline 9 & Memanfaatkan teknologi dalam pembelajaran & $\mathrm{V}$ & \\
\hline 10 & $\begin{array}{l}\text { Menanggulangi keterbatasan di sekolah sesuai dengan cara yang diungkapkan } \\
\text { dalam CoRe }\end{array}$ & & $\mathrm{V}$ \\
\hline \multicolumn{4}{|c|}{ Pengetahuan Konten saat Simulasi Mengajar } \\
\hline 11 & Menyederhanakan materi sesuai dengan tingkat abstraksi peserta didik & $\mathrm{V}$ & \\
\hline 12 & Memberikan contoh yang relevan dengan tingkat abstraksi peserta didik & $\mathrm{V}$ & \\
\hline 13 & Memberikan contoh yang dekat dengan kehidupan peserta didik & $\mathrm{V}$ & \\
\hline 14 & $\begin{array}{l}\text { Mengorganisasikan konsep dari yang paling sederhana menuju yang lebih } \\
\text { kompleks }\end{array}$ & $\mathrm{V}$ & \\
\hline 15 & Menghubungkan materi pelajaran dengan pengalaman peserta didik & $\mathrm{V}$ & \\
\hline \multicolumn{4}{|c|}{ Pengetahuan Pedagogi saat Simulasi Mengajar } \\
\hline 16 & Metode/pendekatan yang digunakan sesuai dengan karakteristik materi & $\mathrm{V}$ & \\
\hline 17 & $\begin{array}{l}\text { Mendorong peserta didik untuk berinteraksi dengan bahan ajar melaui } \\
\text { pertanyaan }\end{array}$ & & $\mathrm{V}$ \\
\hline 18 & Mengembangkan keterampilan proses peserta didik & & $\mathrm{V}$ \\
\hline 19 & Mengembangkan kemampuan bernalar peserta didik & $\mathrm{V}$ & \\
\hline 20 & $\begin{array}{l}\text { Memberi kesempatan bagi peserta didik untuk berinteraksi dengan peserta } \\
\text { didik lain }\end{array}$ & $\mathrm{V}$ & \\
\hline 21 & $\begin{array}{l}\text { Memfasilitasi peserta didik untuk menyusun kesimpulan sendiri atau } \\
\text { mengidentifikasi konsep-konsep penting }\end{array}$ & $\mathrm{V}$ & \\
\hline
\end{tabular}

Tabel 5. Pedoman Observasi Simulasi Mengajar Subjek Penelitian 5

\begin{tabular}{|c|c|c|c|}
\hline No & Pernyataan & $\mathbf{Y a}$ & Tidak \\
\hline \multicolumn{4}{|c|}{ Kesesuaian kegiatan dengan CoRe } \\
\hline 1 & Pengajaran sesuai dengan ide atau konsep yang dituangkan dalam CoRe & $\mathrm{V}$ & \\
\hline 2 & Menekankan pentingnya mempelajari konsep & $\mathrm{V}$ & \\
\hline 3 & $\begin{array}{l}\text { Menyampaikan ide atau konsep yang belum diketahui oleh peserta didik yang } \\
\text { tertuang dalam CoRe }\end{array}$ & & $\mathrm{V}$ \\
\hline 4 & Dapat menangani kesulitan yang terjadi dalam kegiatan pembelajaran & $\mathrm{V}$ & \\
\hline 5 & Meluruskan kemungkinan kesalahan konsep yang terjadi dalam pembelajaran & & $\mathrm{V}$ \\
\hline 6 & $\begin{array}{l}\text { Mempertimbangkan faktor-faktor tertentu yang tertuang dalam CoRe dalam } \\
\text { pembelajaran }\end{array}$ & & $\mathrm{V}$ \\
\hline 7 & Kegiatan pembelajaran sesuai dengan alur yang dirancang dalam CoRe & $\mathrm{V}$ & \\
\hline 8 & Mengevaluasi pemahaman peserta didik sesuai teknik dalam CoRe & $\mathrm{V}$ & \\
\hline 9 & Memanfaatkan teknologi dalam pembelajaran & $\mathrm{V}$ & \\
\hline 10 & $\begin{array}{l}\text { Menanggulangi keterbatasan di sekolah sesuai dengan cara yang diungkapkan } \\
\text { dalam CoRe }\end{array}$ & & $\mathrm{V}$ \\
\hline
\end{tabular}




\begin{tabular}{|c|c|c|c|}
\hline \multicolumn{4}{|c|}{ Pengetahuan Konten saat Simulasi Mengajar } \\
\hline 11 & Menyederhanakan materi sesuai dengan tingkat abstraksi peserta didik & & $\mathrm{V}$ \\
\hline 12 & Memberikan contoh yang relevan dengan tingkat abstraksi peserta didik & & $\mathrm{V}$ \\
\hline 13 & Memberikan contoh yang dekat dengan kehidupan peserta didik & $\mathrm{V}$ & \\
\hline 14 & $\begin{array}{l}\text { Mengorganisasikan konsep dari yang paling sederhana menuju yang lebih } \\
\text { kompleks }\end{array}$ & & $\mathrm{V}$ \\
\hline 15 & Menghubungkan materi pelajaran dengan pengalaman peserta didik & $\mathrm{V}$ & \\
\hline \multicolumn{4}{|c|}{ Pengetahuan Pedagogi saat Simulasi Mengajar } \\
\hline 16 & Metode/pendekatan yang digunakan sesuai dengan karakteristik materi & $\mathrm{V}$ & \\
\hline 17 & Mendorong peserta didik untuk berinteraksi dengan bahan ajar melaui pertanyaan & & $\mathrm{V}$ \\
\hline 18 & Mengembangkan keterampilan proses peserta didik & $\mathrm{V}$ & \\
\hline 19 & Mengembangkan kemampuan bernalar peserta didik & & $\mathrm{V}$ \\
\hline 20 & $\begin{array}{l}\text { Memberi kesempatan bagi peserta didik untuk berinteraksi dengan peserta didik } \\
\text { lain }\end{array}$ & $\mathrm{V}$ & \\
\hline 21 & $\begin{array}{l}\text { Memfasilitasi peserta didik untuk menyusun kesimpulan sendiri atau } \\
\text { mengidentifikasi konsep-konsep penting }\end{array}$ & $\mathrm{V}$ & \\
\hline
\end{tabular}

\section{PEMBAHASAN}

a. Subjek Penelitian 1 (Komponen Ekosistem)

Subjek penelitian 1 termasuk pada subjek penelitian kelompok tinggi (Elvianasti, 2018) yang memiliki nilai konten tinggi dan memiliki nilai tes pedagogi yang tinggi. Dalam penyusunan dokumen CoRe subjek penelitian 1 memiliki ide/konsep yang luas. Dibawah ini adalah pembahasan kemampuan pedagogi dan konten subjek penelitian 1 pada saat simulasi mengajar.

\section{Pedagogy saat Simulasi Mengajar}

Calon guru meminta siswa mengingat kembali materi tentang ekosistem yang telah dipelajari di SMP, lalu meminta siswa mengamati ruang kelas, dan apa saja yang ada disekitarnya. Calon guru menyampaikan tujuan pembelajaran yang akan dicapai. Calon guru memberi pemaparan singkat tentang materi dan kegiatan yang akan dilakukan. Calon guru menanyakan kepada tiap siswa "saat perjalanan menuju sekolah, apakah kalian menemukan makhluk hidup dan makluk tak hidup apa saja? "Calon guru memperlihatkan video tentang sebuah ekosistem sambil mengisi LKS tentang faktor biotik dan abiotik dan mengkonfirmasi jawaban LKS yang telah diisi oleh siswa. Setelah itu, calon guru membagi siswa ke dalam dua kelompok. Calon guru menyuruh siswa mengamati "mini ekosistem" atau replika ekosistem. Calon guru menyuruh siswa melakukan permainan "menyusun ekosistem" dan melakukan pemeriksaan terhadap kerja kelompok siswa. Calon guru memberikan evaluasi kepada siswa berupa pertanyaan sebagai penguatan atas kesimpulan. Calon guru memberi tugas dan menginformasikan pembelajaran selanjutnya. 


\section{Konten saat Simulasi Mengajar}

Dimuka bumi ini terdapat makhluk hidup dan makhluk tak hidup sebagai salah satu komponen penyusun ekosistem. Makhluk hidup disebut juga dengan komponen biotik, seperti hewan, jamur, tumbuhan, virus dan bakteri. Sedangkan, makhluk tak hidup dinamakan komponen abiotik, contohnya : air, tanah, udara, batu. Ekosistem terdiri dari kata "aicos" artinya rumah sendiri dan "systema" artinya bagian utuh yang saling memengaruhi, jadi ekosistem itu adalah sebuah sistem yang didalamnya terjadi hubungan timbal balik dan ada komponen biotik serta abiotiknya. Bangkai hewan dan daun yang sudah jatuh tidak digolongkan pada makhluk hidup karena tidak memiliki ciri makhluk hidup. Individu adalah kumpulan sistem organ yang berdiri sendiri, populasi adalah kumpulan individu dalam satu jenis menempati ruang dan waktu yang sama serta bisa melakukan inbreeding sehingga bisa menghasilkan keturunan yang fertile. Komunitas adalah kumpulan berbagai populasi yang menempati suatu habitat tertentu.

Pengetahuan konten yang disampaikan subjek penelitian 1 untuk ukuran jenjang SMA memiliki kedalaman yang dangkal, konten ini lebih cocok untuk diajarkan di SMP. Tetapi, secara keseluruhan subjek penelitian 1 memiliki kemampuan dalam mengajarkan konsep ini.

\section{b. Subjek Penelitian 2 (Interaksi Antar Populasi)}

Subjek penelitian 2 termasuk pada subjek penelitian kelompok sedang yang memiliki nilai konten sedang dan memiliki nilai tes pedagogi yang tinggi. Dibawah ini adalah pembahasan kemampuan pedagogi dan konten subjek penelitian 1 pada saat simulasi mengajar.

\section{Pedagogy saat Simulasi Mengajar}

Calon guru melakukan kegiatan awal yaitu : mengucapkan salam, mengecek kehadiran siswa, mengecek keadaan kelas, dan memotivasi siswa. Calon guru mengulas materi tentang komponen ekosistem. Calon guru membahas tentang komponen biotik dan abiotik. Calon guru meningkatkan motivasi siswa untuk menjawab pertanyaan guru mengenai interaksi setelah diberi beberapa contoh langsung. Calon guru menuliskan judul pembelajaran pada hari tersebut yaitu mengenai interaksi antar populasi. Calon guru memberitahukan tujuan pembelajaran kepada siswa mengenai materi interaksi antar populasi. Calon guru mengingatkan siswa bahwa minggu lalu sudah ditugaskan untuk membaca materi interaksi antar populasi. Kemudian calon guru mengarahkan siswa untuk memfokuskan perhatian pada gambar yang ditampilkan dengan seksama (mengobservasi). Calon guru mengulas materi dengan menunjukkan gambar jenis interaksi tetapi calon guru tidak memberikan penegasan terhadap jawaban yang dikemukakan oleh siswa. Calon guru membagi siswa dalam beberapa 
kelompok beranggotakan 2-3 orang. Calon guru menjelaskan tentang aturan role playing interaksi antar populasi namun pada saat pembelajaran calon guru kurang mampu mengendalikan/mengatur siswa yang memainkan peran. Calon guru membagikan LKS untuk diisi saat teman kelompok lain tampil. Calon guru memberikan urutan tampil siswa untuk bermain peran didepan kelas secara bergiliran, siswa yang tidak kebagian tampil menuliskan bentuk interaksi antar populasi yang dilakukan temannya di depan kelas ke dalam LKS. Calon guru memberikan evaluasi mengenai materi interaksi antar populasi. Calon guru memberikan nilai-nilai sosial kepada siswa tentang materi interaksi antar populasi dikaitkan dengan kehidupan bermasyarakat. Calon guru memberikan tugas untuk materi selanjutnya mengenai aliran energi.

\section{Konten saat Simulasi Mengajar}

Interaksi antar manusia banyak faktor yang mempengaruhinya. Ketika seorang siswa membantu guru membersihkan papan tulis maka akan terjadi interaksi simbiosis parasitisme karena debu dari papan tulis akan terhirup oleh siswa tetapi ketika siswa merasa ikhlas dan guru akan merasa terbantu maka akan tercipta simbiosis mutualisme. Apabila guru merasa biasa saja ketika memberikan minuman kepada siswa maka akan terjadi interaksi berupa simbiosis mutualisme. Jenis-jenis interaksi individu yaitu : simbiosis mutualisme adalah interaksi individu yang saling menguntungkan, contohnya lebah dengan bunga. Simbiosis komensalisme yaitu interaksi antara dua individu yang satu diuntungkan yang satu biasa saja , contohnya anemon laut dan ikan badut. Simbiosis parasitisme yaitu ketika tali putri yang berwarna kuning mengambil nutrisi dari tanaman hijau/teh yang ditumpanginya. Predasi yaitu ada yang dimangsa dan ada pemangsa yang lebih kuat akan menjadi pemangsa (predator), contohnya : interaksi antara singa dan zebra. Kompetisi adalah dua individu yang menempati ruangan yang sama dan memperebutkan kebutuhan yang sama, contohnya : jika jumlah rumput disuatu daerah sedikit maka akan terjadi kompetisi antara hewan pemakan rumput. Kanibalisme yaitu memakan sesama jenisnya karena dipengaruhi oleh perebutan makanan ketika makanan habis, perebutan pasangan, perebutan wilayah kekuasaan, contohnya : ular dimakan ular. Netral adalah tidak ada interaksi antara dua individu yang berbeda jenis/tidak saling mempengaruhi, contohnya interaksi antara ayam dan kucing karena kucing tidak memakan ayam, capung dengan sapi.

Subjek penelitian 2 mengalami miskonsepsi pada konten, yaitu menjelaskan bahwa hubungan yang terjadi antara manusia merupakan salah satu jenis interaksi simbiosis 
mutualisme/komensalise, padahal hubungan yang terjadi antara manusia bukanlah digolongkan pada interaksi mutualisme/komensalisme.

Secara umum subjek penelitian 2, memiliki ide/konsep yang sempit, ini terlihat dari hasil pedoman observasi. Beberapa point ada yang tidak sesuai dengan dokumen penyusunan CoRe dengan simulasi mengajar.

\section{c. Subjek Penelitian 3 (Aliran Energi)}

Subjek penelitian 3 termasuk pada subjek penelitian kelompok bawah yang memiliki nilai konten bawah dan memiliki nilai tes pedagogi yang rendah. Dibawah ini adalah pembahasan kemampuan pedagogi dan konten subjek penelitian 3 pada saat simulasi mengajar konsep aliran energi.

\section{Pedagogy saat Simulasi Mengajar}

Calon guru memberikan motivasi dengan cara mengingatkan siswa tentang materi sebelumnya dan memberikan acuan pembelajaran : menganalisis alur aliran energi dalam ekosistem dan mengaitkan aliran energi dengan keseimbangan ekosistem. Calon guru membagi siswa ke dalam kelompok yang terdiri dari 2 kelompok besar. Calon guru menjelaskan mekanisme pelaksanaan pengalaman belajar. Calon guru memberikan topeng peran, kartu skenario dari setiap peran dan menyuruh siswa mengisi LKS kemudian perwakilan dari kedua kelompok memainkan peran yang terdapat pada kartu peran. Calon guru menuntun siswa untuk menemukan konsep aliran energi pada rantai makanan. Calon guru memberikan sebuah artikel "meledaknya ulat bulu" dan meminta tanggapan siswa tentang artikel tersebut berkaitan keseimbangan ekosistem. Calon guru menyampaikan manfaat dalam mempelajari aliran energi pada rantai makanan yaitu supaya manusia bisa menjaga keseimbangan ekosistem dengan tidak merusaknya. Calon guru memberikan evaluasi. Calon guru memberikan tugas mengamati rantai makanan di ekosistem buatan (sawah). Calon guru memberikan informasi pembelajaran selanjutnya.

\section{Konten saat Simulasi Mengajar}

Matahari sebagai sumber energi utama, jika tidak ada matahari maka aliran energi tidak akan terjadi, kemudian energi ini akan dipindahkan pada tumbuhan. Tumbuhan mendapatkan energi dari matahari dengan melakukan fotosintesis, kemudian dari fotosintesis tumbuhan (padi) bisa membuat makanan sendiri yang disebut autotrof (produsen dalam rantai makanan) yaitu organisme yang dapat membuat makanan sendiri dengan memanfaatkan sinar matahari. Setelah itu, herbivora (pemakan tumbuhan) contohnya tikus sebagai konsumen tingkat I memakan tumbuhan. Energi yang diperoleh tikus dari tumbuha, energi yang didapatkan 
digunakan sebagai metabolisme dari hasil tersebut tikus menggunakan untuk kegiatannya, energi tersebut diperoleh dari tumbuhan. Konsumen tingkat II merupakan konsumen yang tingkatannya lebih tinggi dari konsumen tingkat I, contohnya adalah ular (karnivora), energinya diperoleh dengan memakan konsumen tingkat I yang digunakan sebagai metabolisme untuk aktivitas sehari-hari. Konsumen tingkat III merupakan konsumen yang paling tinggi tingkatannya memperoleh energi dengan cara memakan konsumen tingkat II , contohnya adalah elang. Komponen selanjutnya adalah pengurai yang berfungsi menguraikan konsumen tingkat III apabila sudah mati setelah diuraikan maka energi yang didapatkan dikeluarkan dalam bentuk panas. Aliran energi mengalir dari sumber energi yang besar dan semakin tinggi tingkatannya maka energi yang diperoleh semakin berkurang, energi tersebut ada yang dipakai dan ada yang dilepaskan tetapi tidak kembali pada sumber energi utama. Terjadinya serangan wabah ulat bulat yang meledak populasinya mengakibatkan kerugian bagi tanaman, masyarakat, dan ada sesuatu yang hilang. Penyebab utama dari kasus tersebut terjadi karena ada predator yang hilang/berkurang sehingga rantai makanan tidak terjadi secara normal maka berdampak pada keseimbangan ekosistem.

Secara umum subjek penelitian 3, memiliki ide/konsep yang sempit, ini terlihat dari hasil pedoman observasi. Beberapa point ada yang tidak sesuai dengan dokumen penyusunan CoRe dengan simulasi mengajar. Selain itu, pengajaran tidak sesuai dengan yang telah dituangkan dalam dokumen CoRe, didalam CoRe subjek penelitian 3 mengatakan bahwa aliran energi merupakan salah satu jenis interaksi. Untuk alur/rancangan pembelajaran yang telah tercantum dalam CoRe tidak sesuai dengan simulasi mengajar, yaitu : akhir dalam pembelajaran materi ini adalah siswa membuat kesimpulan tentang apa yang mereka telah pelajari mengenai aliran energi.

\section{d. Subjek Penelitian 4 (Daur Hidrologi)}

Subjek penelitian 4 termasuk pada subjek penelitian kelompok tinggi yang memiliki nilai konten tinggi dan memiliki nilai tes pedagogi yang sedang. Dalam penyusunan dokumen CoRe subjek penelitian 4 memiliki sedikit ide/konsep tetapi ide/konsep tersebut memiliki alasan yang mendalam. Dibawah ini adalah pembahasan kemampuan pedagogi dan konten subjek penelitian 4 pada saat simulasi mengajar.

\section{Pedagogy saat Simulasi Mengajar}

Pada awal pembelajaran calon guru mengingatkan siswa tentang materi sebelumnya, setelah itu calon guru melakukan demonstrasi dengan cara memasak air di depan kelas yang bertujuan untuk meningkatkan minat belajar siswa. Calon guru menyampaikan tujuan 
pembelajaran yaitu : siswa mampu menjelaskan proses hujan sebagai bagian dari biogeokimia, mampu menjelaskan proses-proses yang terjadi saat daur hidrologi dengan benar. Calon guru menunjukkan gambar orang yang sedang menjemur pakaian di terik matahari kemudian guru memberikan stimulus berupa pertanyaan agar siswa fokus terhadap materi yang akan dipelajari. Calon guru menunjukkan video terbentuknya hujan dari proses penguapan dan kemudian siswa melakukan diskusi mengenai interaksi yang terjadi pada daur hidrologi. Calon guru memberikan penguatan dengan menjelaskan mengenai interaksi yang terjadi pada daur hidrologi. Calon guru mengingatkan siswa untuk tidak merusak lingkungan karena akan mengganggu proses daur nutrient yang sangat penting bagi kehidupan. Calon guru memberikan evaluasi berupa soal yang terdiri dari dua tipe, yaitu soal berupa essay dan menjodohkan. Setelah itu, calon guru memberikan tugas kepada siswa untuk membaca materi daur biogeokimia lainnya seperti : daur hydrogen, daur nitrogen,dll untuk pertemuan berikutnya.

\section{Konten saat Simulasi Mengajar}

Sumber energi yang terbesar adalah matahari, energi tersebut berpindah dari satu makhluk hidup ke makhluk hidup yang lainnya melalui suatu aliran energi dengan cara makan dan dimakan/rantai makanan. Makhluk hidup tidak hanya membutuhkan matahari, manusia juga membutuhkan nutrient lain seperti : karbon, nitrogen, sulfur, fosfor, dll. Keberadaan nutrient tersebut terbatas dimuka bumi ini, semuanya bergantung pada daur ulang nutrient tersebut. Daur ulang tersebut melibatkan komponen ekosistem seperti : komponen biotik dan abiotik sehingga disebut daur biogeokimia. Yang termasuk daur bigeokimia adalah daur air/hidrogen, daur nitrogen, daur karbon, daur oksigen, dll. Ketika air dipanaskan/memperoleh suhu yang tinggi maka air tersebut akan menguap, uap air inilah yang akan menguap ke udara. Setelah air tersebut menjadi uap maka akan terbang ke atmosfer, suhu di atmosfer lebih rendah dari suhu bumi sehingga akan terbentuk padatan/awan proses ini disebut peristiwa kondensasi. Awan akan bergerak karena adanya angin, awan tersebut akan bergabung dengan awan-awan yang lain sehingga membentuk massa/gumpalan yang lebih besar. Selain itu, ketika awan sudah menjadi massa yang besar akan turun ke permukaan bumi yang memiliki suhu tinggi sehingga gumpalan tadi akan jatuh ke permukaan bumi dalam bentuk titik-titik air (hujan), proses ini disebut presipitasi. Ketika hujan turun maka sebagian air ada yang mengalir ke daratan rendah dan ada juga yang diserap oleh tanah, kemudian akan menggenang di bawah tanah yang tidak bisa ditembus oleh air. Pada akhirnya air tersebut akan mengalir kedaratan rendah juga, proses tersebut akan terus belanjut. Uap air yang 
mendapatkan suhu yang lebih panas akan kembali menjadi tetesan-tetesan air. Penguapan tidak hanya terjadi pada air permukaan saja tapi tumbuhan juga mengalami penguapan yang disebut respirasi, selain itu tumbuhan juga melakukan gutasi atau mengembun (transpirasi) karena hasil dari penguapan tumbuhan tersebut. Sedangkan, manusia dan hewan melakukan penguapan dalam bentuk keringat dan urin. Berbeda halnya dengan pembentukan salju disebabkan karena suhu lingkungan yang rendah setelah air tersebut terkondensasi uap air tetap menjadi beku. Daur hidrologi pada prinsipnya adalah air dibumi menguap ke atmosfer karena dipengaruhi oleh panas matahari, sebagian air hujan yang turun ke bumi diserap oleh tumbuhan, dan untuk keperluan manusia lainnya, sisanya akan mengalir ke permukaan tanah menuju sungai, danau, dan bawah tanah, pada akhirnya air tersebut akan bermuara di laut dan membebaskan air ke atmosfer melalaui respirasi pada tumbuhan dan ekskresi pada hewan. Proses yang terjadi pada saat pembentukan hujan : 1. Evaporasi yaitu penguapan yang terjadi pada air permukaan, 2. Kondensasi yaitu perubahan uap air menjadi bentuk yang lebih padat/pembentukan awan, 3 . Presipitasi yaitu air akan turun ke bumi dalam bentuk hujan, 4. Ilfiltrasi yaitu gerakan air saat menembus permukaan tanah.

Berdasarkan hasil pedoman observasi dan dokumen CoRe, subjek penelitian 4 memiliki kemampuan dalam mengajarkan konsep ini. Subjek penelitian memiliki ide/konsep yang luas, jika dibandingkan dengan subjek kelompok sedang dan bawah. Seperti pertanyaan, mengapa konsep ini penting untuk siswa? Subjek penelitian 4 menjawab : konsep ini penting untuk dikuasai siswa karena di dalamnya membahas tentang bagaimana daur ulang nutrien yang sangat diperlukan oleh makhluk hidup yang ketersediaanya terbatas, sehingga nutrien-nutiren tersebut keberadaannya bergantung pada daur ulang yang melibatkan komponen ekosistem. Setelah siswa mempelajari materi ini diharapkan mereka dapat menganalisis semua interaksi yang berlangsung di dalamnya. Jika dibandingkan kelompok sedang yang menjawab : agar siswa dapat memanfaatkan setiap proses dan hasil dari setiap daur, dan kelompok bawah: karena siklus biogeokimia terjadi dalam kehidupan sehari-hari dan merupakan hal penting dalam suatu ekosisem.

Berdasarkan hasil pedoman observasi simulasi mengajar, secara umum subjek penelitian 5 mengalami banyak ketidaksesuaian antara simulasi mengajar dengan dokumen CoRe yang telah disusun. Kemudian berdasarkan hasil wawancara menurut subjek penelitian 5, strategi mengajar yang digunakan saat simulasi mengajar merupakan strateigi yang terbaik sehingga tidak memiliki keinginan untuk memperbaiki strategi yang telah digunakan. Selain itu, subjek penelitian 5 memiliki ide/konsep yang sempit jika dibandingkan dengan kelompok atas 
ataupun kelompok sedang, terlihat dari simulasi mengajar dan dokumen CoRe subjek penelitian hanya menjelaskan macam-macam pencemaran dan polutannya

e. Subjek penelitian 5 (Polusi)

Subjek penelitian 5 termasuk pada subjek penelitian kelompok bawah yang memiliki nilai konten rendah tetapi memiliki nilai tes pedagogi yang tinggi. Dibawah ini adalah pembahasan kemampuan pedagogi dan konten subjek penelitian 5 pada saat simulasi mengajar.

1. Pedagogy saat Simulasi Mengajar

Pada awal pembelajaran calon guru mengingatkan siswa tentang materi sebelumnya. Calon guru menanyakan kepada siswa "apa itu hujan asam?. Calon guru menyampaikan tujuan pembelajaran yang akan dicapai oleh siswa yaitu : menyebutkan jenis-jenis polusi, memahami faktor penyebab terjadinya polusi. Calon guru menampilkan video tentang pencemaran lingkungan dan meminta siswa untuk memahaminya. Calon guru menjelaskan jenis-jenis pencemaran yang terjadi di lingkungan sekitar siswa. Calon guru membagi siswa menjadi dua kelompok dan membagikan LKS. Calon guru meminta perwakilan siswa untuk mengambil bahan-bahan percobaan sederhana mengenai polusi air dan polusi tanah. Calon guru memfasilitasi siswa untuk melakukan percobaan sederhana kemudian siswa mengumpulkan data dari hasil percobaan yang dilakukan. Calon guru meminta siswa untuk menampilkan hasil percobaan yang telah dilakukan. Calon guru memberikan evaluasi berupa posttest kepada siswa. Calon guru bersama siswa membuat rangkuman atau kesimpulan pelajaran. Calon guru mengingatkan siswa untuk tetap menjaga lingkungan demi keberlangsungan hidup generasi selanjutnya. Calon guru menugaskan siswa membuat rangkuman mengenai materi selanjutnya (konservasi).

\section{Konten saat Simulasi Mengajar}

Hujan asam adalah hujan yang secara alami bersifat asam karena bereaksi dengan $\mathrm{CO}_{2}$ di udara. Hujan asam yang berbahaya dikarenakan reaksi antara sulfur/belerang $+\mathrm{O}_{2}=$ sulfurdioksida + air $=$ asam sulfat yang akan turun bersama hujan. Jika hujan asam ini bersifat pekat maka akan berbahaya bagi makhluk hidup. Jenis-jenis polusi : udara, air, tanah, dan suara. Polutan adalah bahan pencemar yang menyebabkan pencemaran/polusi. Kriteria polutan adalah ada ditempat yang tidak semestinya dalam jumah yang banyak, contohnya : limbah, bahan-bahan organik dan anorganik yang ada di sungai dalam jumlah yang banyak. Polutan dari polusi suara ada : bunyi mesin mobil, petir, suara kereta api tetapi polutannya tersebut tergantung bagaimana seseorang memandangnya, 
dikatakan polutan apabila sudah mengganggu atau menyebabkan kebisingan. Polusi udara disebabkan karena transportasi, pembangkit listrik/nuklir, industri dan pembakaran. Polusi tanah bisa terjadi karena ada bahan kimia industri.

Berdasarkan hasil pedoman observasi simulasi mengajar, secara umum subjek penelitian 5 mengalami banyak ketidaksesuaian antara simulasi mengajar dengan dokumen CoRe yang telah disusun. Subjek penelitian 5 memiliki ide/konsep yang sempit jika dibandingkan dengan kelompok atas ataupun kelompok sedang, terlihat dari simulasi mengajar dan dokumen CoRe subjek penelitian hanya menjelaskan macam-macam pencemaran dan polutannya.

\section{PENUTUP}

1. Subjek Penelitian 1 memiliki penguasaan konten tinggi, dan penguasaan pedagogi tinggi. Terdapat kesesuaian antara simulasi mengajar dengan dokumen CoRe.

2. Subjek penelitian 2, memiliki penguasaan konten rendah, dan penguasaan pedagogi tinggi. Beberapa point ada yang tidak sesuai dengan dokumen penyusunan CoRe dengan simulasi mengajar.

3. Subjek penelitian 3, memiliki penguasaan konten rendah, dan penguasaan pedagogi rendah. Ketidaksesuaian dokumen CoRe dengan simulasi mengajar.

4. Subjek penelitian 4, memiliki penguasaan konten tinggi, dan penguasaan pedagogi sedang. Terdapat kesesuaian antara simulasi mengajar dengan dokumen CoRe.

5. Subjek penelitian 5, memiliki penguasaan konten rendah, dan penguasaan pedagogi rendah. Ketidaksesuaian dokumen CoRe dan dengan simulasi mengajar.

6. Sehingga dapat disimpulkan bahwa calon guru yang memiliki konten tinggi dan pedagogi tinggi terdapat kesesuaian CoRe dengan simulasi mengajar, dan calon guru yang memiliki konten rendah dan pedagogi rendah terdapat ketidaksesuaian CoRe dengan simulasi mengajar. Akan tetapi,ada calon guru yang memiliki pedagogi tinggi dan konten rendah terdapat ketidaksesuian CoRe dengan simulasi mengajar. 


\section{REFERENSI}

Elvianasti, Mega, Purwianingsih, Widi. \& Riandi. (2016). Analisis Pedagogy Knowledge (PK) Mahasiswa Calon Guru Biologi pada Konsep Genetika dan Ekologi. Jurnal Sigma. No. 01 Vol. VIII, Juni 2016. ISSN: 1411-5166.

Elvianasti, Mega. (2018). Analysis of CK (Content Knowledge) of Pre-service Biology Teachers on Concept of Genetics and Ecology. Jurnal Biodidaktika. No. 01 Vol. 13. ISSN: 2527-4562.

Hagevik, R., et al. (2009). Pedagogical Content Knowledge and the 2003 Science Teacher Preparation Standards for NCATE Accreditation or State Approval. J Sci Teacher Educ (2010) 21: 7-12. Springer Science+Business Media, Published Online : 26 November 2009.

Hayati, I., \& Sujadi, E. (2018). Perbedaan Keterampilan Belajar Antara Siswa IPA dan IPS. Tarbawi : Jurnal Ilmu Pendidikan, 14(1), 1-10. doi:10.32939/tarbawi.v14i1.250

Hudson, P. (2007). Examining mentors' practices for enhancing preservice teachers' pedagogical development in mathematics and science. Mentoring and Tutoring,15(2), 201-217. doi:10.1080/13611260610186394

Loughran J., Amanda Berry \& Pamela Mulhall. (2006). Understanding and Developing Science Teachers' Pedagogical Content Knowledge. Rotterdam: Sense Publishers.

McMillan, J.H \& Schumacher, S. (2001). Research In Education. Fifth Edition. New York: Longman.

Sujadi, E. (2017). Penerapan Pendidikan Karakter Cerdas Format Kelompok untuk Meningkatkan Nilai Kejujuran Mahasiswa Bimbingan Konseling Islam (BKI) Institut Agama Islam Negeri (IAIN) Kerinci. Tarbawi : Jurnal Ilmu Pendidikan, 13(1), 97-108 